\section{International Scientific Journal Theoretical \& Applied Science}

\author{
p-ISSN: 2308-4944 (print) e-ISSN: 2409-0085 (online) \\ Year: 2017 Issue: 11 Volume: 55 \\ Published: $27.11 .2017 \quad$ http://T-Science.org
}

\section{Shargiya Akif gizi Hasanova}

Doctor of Philosophy in Philology, Associate Professor, Head of the Department of Russian Language and Intercultural Communication of the

Baku Slavic University, turkologiya@mail.ru

SECTION 29. Literature. Folklore. Translation

Studies.

\title{
THE CONCEPT OF "MIND" IN THE RUSSIAN LANGUAGE PICTURES OF THE WORLD
}

Abstract: In the article with the application of conceptual analysis, the concept "mind" is examined and the signs of its structure as a concept are revealed, the scope of functioning is presented. As a result of the research, ways of verbalizing the concept "mind" and its signs as a concept have been revealed, cognitive models and metaphors have been characterized in the semantic space of the Russian language, the cognitive side of man's metaphorical activity, oriented to cognition, that reflects the intellectual environment.

Key words: concept, language picture of the world, mind, mentality.

Language: Russian

Citation: Hasanova SA (2017) THE CONCEPT OF MIND IN THE RUSSIAN LANGUAGE PICTURES OF THE WORLD. ISJ Theoretical \& Applied Science, 11 (55): 185-188.

Soi: http://s-o-i.org/1.1/TAS-11-55-23 Doi: crostef https://dx.doi.org/10.15863/TAS.2017.11.55.23

\section{УДК 811}

\section{КОНЦЕПТ «УМ» В РУССКОЙ ЯЗЫКОВОЙ КАРТИНЕ МИРА}

Аннотация: В статье с применением концептуальный анализ рассматривается концепт «ум» $u$ выявлены признаки его структуры как конщепт, представлена сфера функционирования. В результате исследования выявлены способы вербализаџии концепта «ум» $u$ его признаки как концепт, охарактеризованы когнитивные модели и метафоры в семантическом пространстве русского языка, намечена познавательная сторона метафорической деятельности человека, сориентированная познанию, которая отражает интеллектуальную среду.

Ключевые слова: концепт, языковая картина мира, ум, ментальность.

\section{Introduction}

Тема настоящей статьи - описание образа ума как одного из составляющих отрывков картины мира «умственные способности человека». Выбранный нами для анализа концепт характеризует интеллектуальные возможности человека, и принадлежат к универсальным категориям, определяющим человеческое мышление. В русской культуре концепт «ум» отличается от других (душа, сердце, разум) своим ценностным статусом.

\section{Materials and Methods}

Одним из основных способов концептуального анализа является описание концептов в виде выделения их признаков. Связано это с тем, что когнитивная категоризация происходит на основании какого-либо наиболее «бросающего в глаза» признака. Еще Платон обсуждал вопрос о том, являются ли слова орудиями познания и связаны ли они с действительностью. Впоследствии Аристотель совершенно определенно выводил значения слов за пределы языка. Согласно теории Э. Рош, такие признаки называются прототипичными. Сторонники теории когнитивной категоризации (C.B. Вишаренко, В.3. Демьянков, А.А. Залевская, Е.С. Кубрякова, Л.Г. Лузина, Е.А. Пименов, М.В. Пименова, З.Д. Попова, Е.В. Рахилина, И.А. Стернин) также подчеркивают, что эти признаки, как правило, не поддаются четкому определению. Поэтому говорят о типичном представителе категории, который в наиболее полном и совершенном виде обладает прототипичными когнитивными признаками [5].

Обычна концепт «ум» связывается в коллективном сознании с мыслительной инерцией субъекта. Лексема ум пришла в русский 
язык из греческого языка через старославянский язык. В «Словаре русского языка» С.И.Ожегова и Н.Ю. Шведовой лексическое значение словаконцепта ум следующее:

«Ум - 1) способность человека мыслить, основа сознательной, разумной жизни; 2) такая способность, развитая в высокой степени, высокое развитие интеллекта; 3) перен. О человеке как носителе интеллекта» [4, р.820].

Представление об уме в культуре русского народа широко отражено в текстах, фиксирующих многовековой опыт народа, - в пословицах, поговорках, устойчивых выражениях. В словаре В.И. Даля приводятся более шестисот пословиц и поговорок, актуализирующих понятия «ум» и «глупость» [2]. Это представление своеобразно и многопланово. Ученые указывают 23 группы признаков, присущих русскому концепту «ум»: вегетативные, зоологические, анималистические, гендерные, социальные и др. [5, p.5].

Инвариантными семами слова-концепта $y_{м}$ являются такие, как «мыслительная способность», «способность мышления и понимания». Нередко ум отождествляется с понятиями разум, сознание, дух, интеллект. В русском языке эквиваленты для всех представленных значений таковы: $y м$, разум, умственные способности, мышление, память, намерение.

В русском языке достаточно ярко выражены фразеологизмы, содержащие оценку умственного развития человека. Их можно разбить на две группы:

1) фразеологизмы, характеризующие высокий уровень умственного развития: ума палата, набираться ума, семи пядей во лбу, иметь голову на плечах;

2) фразеологизмы, характеризующие низкий (очень низкий) уровень умственного развития человека: олух ияаря небесного, без иаря в голове, набитый дурак, отпетый дурак, кругльй дурак, глуп как сивый мерин (баран, пробка), дубина стоеросовая и др.

Для единиц фразеологического поля «Уственные способности» важнейшими являются два признака - способность и состояние. Это приводит к классификации фразеологизмов по следующим направлениям: а) умственных способностей / менталитета как способности к намерению / осуществлению деятельности; б) умственных способностей / менталитета как состояния, проявляющегося в адекватном / неадекватном поведении.

Образно-ассоциативный комплекс значений, находящий отражение во внутренней форме фразеологизмов, обнаруживает образы, стереотипы, эталоны, символы, носящие отпечатки культурно-национального сознания носителя языка. Образ ума отражает путь номинации, выделенной в мире абстракции, ее осознание. Ум - это абстракция, и развитие осознания и проникновения в сущность выделенной абстракции отражено во фразеологизмах, в которых ум атрибутируется: делать что-либо с умом, ум срабатыввает, ума не купишь и др., т.е. здесь наблюдается реализация ума как вещи: Я думаю, тут какой-то подкорковый $y_{м}$ срабатьвает (Фазиль Искандер, «Сандро из Чегема»). Таким образом, можно выделить следующий концепт основания для ума:

1) ум как вещь: купить/ продать ум, растерять ум, вынести ум, раскинуть умом / умишком, копить ум, лишить ума, ума не прибавить, ум не передать, раздавать /весь/ свой/ ум, вложить ум, вбивать ум, обноситься умом;

2) ум как вещь/инструмент: взяться/браться с умом, взяться за ум, с умом делать что-либо; подойти к чему-либо с умом, ум сработает;

3) ум как нечто органическое: ум высох, засох, ослабеть умом, ум помутился, ум застоялся, проветрить ум, ум вырос;

4) ум как локация: взять в толк, не умешчается в уме, не укладывается в уме, в уме отпечаталось, себе на уме, три пишем, два на ум берем; ума палата.

Фразеологизм ума палата имеет следующее значение: человек очень умён. Имеется в виду, что субъект, который обладает высокими умственными способностями, обширными познаниями, очень хорошо образован: «Александр Ильич, хоть он и ума палата, и учён, и энергичен, без такой жены, как вы, не был бы тем, чтоо он есть» (П. Боборыкин, «Поумнел»).

Компонент палата соотносится с вещным и пространственным кодом культуры. Образ фразеологизма создаётся совокупностью вещной и пространственной метафор и метонимией, при которой $y_{\mu}$ (способность мыслить) отождествляется с телесной частью человека - c мозгом, серым веществом. Обладание таким веществом в большом объёме осознаётся как несомненная ценность. Смысл объёма и ценности отображён в образе палаты - большого и богатого украшенного помещения, хранилища драгоценностей;

5) ум как состояние:

а) состояние как вещь: ума лишиться, потерять ум, утратить ум;

б) состояние как нечто органическое: помутиться умом, ослабеть умом,

в) состояние как локация: $в$ здравом/полном/своем/чужом уме, выжить из ума, сойти с ума, спятить /спрыгнуть с ума, помешаться в уме, не в своем уме. 
Таким образом, ум предстает в том или ином образе: в образе вещи, которую человек утратил, и в связи с этим его состояние изменяется, что проявляется в поведении; ум в образе локации, в которой свойственно пребывать человеку; изменение пребывания влечет за собой изменение психофизиологического состояния.

Концепт «ум» может быть представлен признаками предметов, которые созданы руками человека, когда реализуется когнитивная модель «ум - контейнер/вместилище» (дырявая сума, наполнить ум, глубокий ум). Данная модель характеризуется пространственными признаками вместилища и функциональными особенностями: ум - это место, в котором хранят информацию память (хранить в уме, держать в уме): Ты еще мал годами, чтобы зло в уме держать (Ф. Гладков, Повесть о детстве); А тогда мы не только доход могли в уме держать (С. Г. КараМурза, «Совок» вспоминает свою жизнь»). Ср.: в русских пословицах и поговорках: Голова без ума, что фонарь без свечи; Без ума голова котел; Без ума голова - лукошко.

$\mathrm{У}_{\mathrm{M}}$ в русских паремиях имеет свою материальную локализацию в голове (речь идет об области лба и висков): Голова без ума что фонарь, без свечи; Ум не в бороде, а в голове. В этих паремиях подчеркивается ценность ума, без него голова человека представляется абсолютно ненужной и бесполезной частью тела: Голова что чан, а ума ни на капустный кочан; Голова с пивной котел, а ума ни ложки; Голова с лукошко, а мозгу ни крошки [3, p.64-67].

Голова осмысляется как источник любых начинаний человека, ср.: Голова - всему начало; Где ум, там и толк. Здесь важно подчеркнуть, что любое дело следует предпринимать обдуманно, тогда будет результат. При этом в некоторых пословицах и поговорках характеристика ума присваивается каждому человеку, обладающему головой, ср.: Сколько голов - столько и умов; Что голова, то разум. Однако в русском языковом сознании существуют и такие паремии, которые отражают прямо противоположное значение, ср.: Не всяк умен, кто с головою [1, p.157-158]. См. до конца. Цитирование по мере упоминания в тексте. Конкретные страницы

В пословичном фонде русского языка частотны единицы со смысловым компонентом 'количественные характеристики ума'. Ум в сознании русского народа - это нечто количественно измеряемое. В языковой картине русских людей отражена способность ума накапливаться, увеличиваться, человек может растерять разум, растратить его по частям, ср. русские паремии: В умной беседе быть - ума прикупить, а в глупой - и свой растерять. Для русского народа важно количество, большой объем ума, ср.: Ум - хорошо, а два - лучше; Сто голов - сто умов [1, p.167].

Показателен в этом смысле фразеологизм ума набраться, относящийся к разговорному стилю: набираться ума (разума), набраться ума (разума). Разг. Экспресс. Умнеть, становиться рассудительным, умным: С хорошим человеком и говорить хорошо, ума наберёшься (Л.Толстой. Первый винокур); У тебе, сват Фома, люди ходят ума-разума набираться (Ф. Гладков. Повесть о детстве). Фразеологизм состоит из двух лексем ум и набраться: первая лексема нейтральная, лексема набраться - просторечная. Обе лексемы в другой языковой ситуации, вне фразеологизма, являются лексемами, которые могут свободно употребляться, однако во фразеологизме утрата одного слова ведет к разрушению всей фразеологической единицы [5].

Лингвистический и культурологический аспект этого фразеологизма можно определить, опираясь на лексему набраться, внутренняя форма которого заложена в корне, образующем лексему брать. Содержание просторечия набраться определяется лексемой литературного языка «брать - взять, захватывать руками, хватать, принимать, получать, держать, присваивать [2, р.120]. Инфинитив брать с приставкой на - приобретает при этом другой оттенок как в содержании, так и в стилистической маркированности, в результате чего анализируемый фразеологизм приобретает переносное значение.

Фразеологизмы с компонентом $y_{M}$ могут входить в активный или пассивный состав языка и обладать различными стилистическими оттенками. К примеру, фразеологизм спрыгнуть с ума имеет следующие пометы: устар., прост. 1. Лишиться рассудка. (слова Фамусова); По матери пошёл, По Анне Алексевне; покойница с ума сходила восемь раз. (слова Хлёстова) На свете странные бывают приключенья! В его лета с ума спрыгнул (А.Грибоедов. «Горе от ума»); фразеологизм выжить из ума - пометы: (фам.) Старик встал и пошёл прочь, злобно ворча. - Из ума ты выжнваешь, Тяпа, - убеждённо сказал вслед ему учитель (М. Горький, «Бывшие люди»); (ирон.) Вот ведь какое со мной горе! Всё одна да одна, совсем из ума выюила (Ф. Абрамов, Пелагея); фразеологизм себе на уме [4, р.586]: разг., неодобр. Скрытен, хитер, не обнаруживает своих мыслей, намерений. С сущ. со знач. лица: Этот человек опытный, себе на уме, не злой и не добрый, а более расчетливый... (И. Тургенев. «Певцы»); Этот молчит, стало быть, себе на уме... (А. Чехов, «В Москве на Трубной площади»).

В лингвистическом и культурологическом пространстве фразеологизм задним умом крепок достаточно точно отражает взаимодействие 
диахронного и синхронного уровня. В процессе исторического развития этот фразеологизм становится менее частотным. Так как первоначально эта единица служила для характеристики «мужика», который, был безграмотным человеком, не обладал знаниями, чтобы быстро решить ту или иную проблему, но обладая природным умом, смекалкой, он все-таки находил, то решение, которое ему было нужно, и фразеологизм четко отражал процесс мышления «мужика». На современном этапе развития общества этот фразеологизм становится менее актуальным, так как человек в современном мире наделен в большей или меньшей степени знаниями.

Признак артефакт может реализовываться через когнитивную модель «ум - драгоценность» (драгоиенный ум). Когнитивная модель «ум драгоценный камень» может актуализироваться признаком блеск (блестящзий ум). Признак артефакт реализуется через когнитивную модель «ум - оружие». Ум может представляться признаками оружия, которым наносят удар (убить умом). Оружие должно быть в хорошем состоянии, чтобы быть готовым нанести удар (отточенный $у м$ ). Когнитивная модель «ум оружие» выражается через признак острота (острый ум): За неброскими, но необычайно точными фразами и формулировками Татьяны просматривались острый ум и немалая житейская мудрость (М.Милованов. «Рынок тщеславия») [5].

\section{Conclusion}

Исследование показало что концепт «ум» в зависимости о своего значения имеет очень обширную поле использования. Это связана с возможностью определить умения, навыки и способности человека связанные с мыслительной деятельностью. В зависимости от этого концепт «ум» становится важным элементом и устной, и письменной речи русского языка, и тем самым он отличается от других концептов внутреннего мира человека.

\section{References:}

1. Birikh A.K., Mokienko V.M., Stepanova L.I. (1999) Slovar' russkoy frazeologii. Istorikoetimologicheskiy spravochnik. SPb.: FolioPress, 1999. -704 p.

2. Dal' V.I. (1955) Tolkovyy slovar' zhivogo velikorusskogo yazyka: v 4 t. I-IV. Moskva: Izdatel'stvo inostrannykh i natsional'nykh slovarey, 1955. T. I. -683 p.

3. Dzyuba E.V. (2011) Kontsept «um» v russkoy lingvokul'ture. Monografiya. Ekaterinburg: Ural'skiy gosudarstvennyy pedagogicheskiy universitet, 2011. -224 p.

4. Ozhegov S.I., Shvedova N.Yu. (2000) Tolkovyy slovar' russkogo yazyka. Moskva: Azbukovnik, 2000. -944 p.

5. Sergeeva N.M. (2004) Kontsepty um, razum v russkoy yazykovoy kartine mira: avtoref. dis. ... kand. filol. nauk. Kemerovo, 2004, -24 p.
6. Sergeeva H.M. (2002) Mental'nye priznaki kontseptov um i razum II Vestn. Kemer. gos. un-ta. Kemerovo: KGU, 2002. - Vyp. 4 (12). p. $125-130$.

7. Slyshkin G.G. (2000) Ot teksta k simvolu. Lingvisticheskie kontsepty pretsedentnykh tekstov v slushanii ili diskurse. M.: Nauka, 2000. - 186 p.

8. Ubiyko V.I. (1998) Kontseptosfera vnutrennego cheloveka v russkom yazyke: Funktsional'no kognitivnyy slovar'. — Ufa: BGU, 1998. -232 p.

9. Fasmer M. (1996) Etimologicheskiy slovar' russkogo yazyka: V 4 t. - SPb.: Azbuka, 1996. T.4. - 864 p.

10. Khrolenko A.T. (2002) Lingvokul'turologiya. Kursk: KGU, 2002. -295p. 